\title{
SISTEM OTOMASI LAYANAN SIRKULASI DENGAN MENGGUNAKAN RADIO FREQUENCY IDENTIFICATION DI PERPUSTAKAAN UNIVERSITAS PENDIDIKAN GANESHA
}

\author{
Putu Tika Parmawati ${ }^{1}$, Putu Sukayana ${ }^{2}$ \\ UPT Perpustakaan \\ Universitas Pendidikan Ganesha \\ Singaraja-Bali
}

e-mail: tika.parmawati@gmail.com,nayorkcity@yahoo.co.id

\begin{abstract}
Abstrak
Kegiatan penelitian ini adalah merupakan penelitian pengembangan yang bertujuan menghasilkan rancangan dan perangkat lunak Sistem Otomasi Layanan Sirkulasi dengan menggunakan Radio Frequency Identification sebagai alternatif layanan sirkulasi di perpustakaan. Sistem otomasi layanan sirkulasi dengan menggunakan Radio Frequency Identification dikembangkan menggunakan metodologi prototyping. Proses analisis kebutuhan dan pengumpulan data dilakukan melalui metode observasi dokumen, observasi lapangan dan studi literatur. Penelitian ini dilaksanakan di Perpustakaan Universitas Pendidikan Ganesha. Penelitian ini menghasilkan sebuah perangkat lunak Sistem Otomasi Layanan Sirkulasi dengan menggunakan Radio Frequency Identification. Perangkat lunak yang dihasilkan mampu memberi kemudahan dan efisiensi dalam pemberian layanan sirkulasi di perpustakaan.
\end{abstract}

Kata Kunci: Otomasi, Radio Frequency Identification, dan Perpustakaan

\begin{abstract}
The aims of the research were to produced Circulation Services Automation System using Radio Frequency Identification design and software as an alternative circulation services at the library. Circulation Services Automation System using Radio Frequency Identification was developed used a prototyping method. The process of needs analysis and data collection were done through observation of documents, field observations and literature studies. The research was conducted in the University of Ganesha Education's Library. This research resulted in a software Circulation Services Automation System using Radio Frequency Identification. The resulted software is able to provides convenience and efficiency in service delivery at the library circulation.
\end{abstract}

Keywords : Automation, Radio Frequency Identification, and Library 


\section{PENDAHULUAN}

Penerapan teknologi informasi (TI) saat ini telah menyebar hampir di semua bidang tidak terkecuali di perpustakaan. Perpustakaan sebagai institusi yang bertugas mengelola bahan pustaka, baik berupa buku maupun bukan berupa buku (non book material) sehingga dapat digunakan sebagai sumber informasi oleh setiap pemakainya. Perkembangan TI dewasa ini memungkinkan seluruh kegiatan perpustakaan memanfaatkan teknologi informasi. Kebutuhan akan TI sangat berhubungan dengan peran dari perpustakaan sebagai kekuatan dalam pelestarian dan penyebaran informasi ilmu pengetahuan dan kebudayaan.

Pengimplementasian TI secara optimal sangat diperlukan dalam layanan perpustakaan. Karena sebagian besar pekerjaan-pekerjaan yang dilakukan di perpustakaan berupa layanan kepada pemakai, sehingga diperlukan metodemetode pelayanan yang bersifat cepat, mudah dan efisien. Layanan perpustakaan meliputi layanan sirkulasi, layanan refrensi dan layanan ruang baca (Bafadal, 2005). Mutu layanan perpustakaan dapat diukur dari dari kemampuan memberikan informasi bahan pustaka yang tepat dan kemampuan memberikan layanan yang cepat, efisien dan akurat kepada pemakainya.

Perpustakaan sebagai pemberi layanan kepada pemakai atau pengunjung memerlukan metodemetode pelayanan yang bersifat cepat, mudah, dan efisien. Perpustakaan selalu dituntut untuk memberikan layanan optimal kepada pengguna perpustakaan. Perpustakaan Pusat
Universitas Pendidikan Ganesha (Undiksha) dalam memberikan layanan kepada pemustaka sudah memanfaatkan sistem informasi berbasis teknologi informasi. Sistem informasi yang diterapkan di Perpustakaan Undiksha menangani database buku, pembuatan kartu, layanan sirkulasi, layanan OPAC (Online Public Access Catalog) dan menangani denda keterlambatan buku. Sistem informasi yang diterapkan di Undiksha masih memiliki beberapa kelemahan, yaitu : dalam pemberian layanan sirkulasi kepada pemustaka masih mengalami kesulitan karena petugas harus memasukkan satu per satu kode buku dan memilih nomor inventaris buku yang dipinjam sehingga waktu pemberian layanan relatif lama. Uraian diatas memberikan gambaran bahwa sistem informasi yang diterapkan di Undiksha masih memiliki kelemahan dalam pemberian layanan kepada pemustaka.

Kemajuan teknologi informasi dan komputer (TIK) yang merupakan perpaduan antara dunia teknologi informasi dan komputer dengan menawarkan peluang sangat besar untuk menunjang kelancaran tugastugas di berbagai bidang kehidupan termasuk di dalamnya bidang perpustakaan. Perpustakaan sebagai institusi pengelola informasi merupakan salah satu bidang penerapan teknologi informasi yang berkembang dengan pesat. Salah satu fitur yang dapat dikembangkan dalam bidang perpustakaan adalah otomasi layanan sirkulasi dengan menggunakan RFID (Radio Frequency Indentification). 
Pemanfaatan RFID dalam pemberian layanan perpustakaan memberi kemudahan kepada petugas dalam melayani pengunjung perpustakaan. Sehingga petugas dapat melayani keperluan pengguna seperti permintaan akan akses yang lebih cepat ke informasi yang diperlukan pengguna perpustakaan. Otomasi layanan perpustakaan dengan menggunakan RFID dipilih menjadi alternatif pemberian layanan mengingat jumlah pengguna layanan perpustakaan Undiksha yang terus meningkat. Dari paparan di atas maka dipandang perlu untuk menerapkan sistem otomasi layanan perpustakaan dengan menggunakan RFID.

Dari uraian di atas maka penelitian ini bertujuan untuk menjawab permasalahan yaitu pertama, untuk mendeskripsikan bagaimana rancangan sistem otomasi layanan sirkulasi dengan menggunakan RFID di Perpustakaan Universitas Pendidikan Ganesha? dan yang kedua, untuk mendeskripsikan bagaimana implementasi sistem otomasi layanan sirkulasi dengan menggunakan RFID di Perpustakaan Universitas Pendidikan Ganesha?

Hasil penelitian ini diharapkan dapat mendeskripsikan rancangan sistem otomasi layanan sirkulasi dengan menggunakan RFID di Perpustakaan Universitas Pendidikan Ganesha dan dapat mendeskripsikan implementasi coding program sistem otomasi layanan sirkulasi dengan menggunakan RFID di Perpustakaan Universitas Pendidikan Ganesha.

\section{METODE PENELITIAN}

Rancangan yang digunakan dalam penelitian ini adalah rancangan penelitian pengembangan (Sugiyono, 2009). Pengembangan sistem otomasi layanan sirkulasi dengan menggunakan RFID sebagai sebuah produk akhir dari penelitian ini menggunakan paradigma prototyping yang merupakan paradigma pengembangan sebuah perangkat lunak.

Validasi yang dilakukan untuk produk dari penelitian ini dibagi menjadi 2 tahapan, yaitu sebagai berikut. (a) Validasi produk secara teknik, produk sistem otomasi layanan sirkulasi dengan menggunakan RFID akan divalidasi dengan tes pengujian yang dilakukan sesuai dengan tahapan metode prototyping. (b) Validasi produk oleh ahli, ahli yang dilibatkan dalam penelitian ini adalah ahli dalam pengembangan perangkat lunak (software) adalah berdasarkan angket yang diberikan kepada ahli dalam pengembangan perangkat lunak.

Sesuai desain pengembangan perangkat lunak prototyping (Pressman, Roger S., 2002), tahap-tahap pengembangan yang dilakukan adalah 6 tahap, yaitu sebagai berikut. (1) Tahap pengumpulan kebutuhan dan perbaikan Pengumpulan kebutuhan perangkat lunak yang akan dibangun meliputi datadata yang diperlukan, pengecekan data yang telah ada maupun yang belum ada. Data-data diperoleh dengan teknik observasi dan studi literatur. (2) Tahap perancangan desain cepat Data-data yang telah terkumpul pada tahap sebelumnya dipergunakan untuk merancang desain awal dari produk yang akan dibangun yang biasanya masih bersifat global. Untuk langkah awal, perancangan desain cepat terutama dapat dilakukan pada bagian 
tampilan. (3) Tahap membangun prototipe Berdasarkan desain awal yang telah ditetapkan maka mulai dilakukan pengimplementasian untuk memperoleh produk yang diharapkan. Jenis prototipe ada 3 yaitu: prototipe di atas kertas, prototipe kerja (prototipe yang telah diimplementasikan ke dalam bahasa pemrograman, sehingga dapat dieksekusi namun belum berjalan sempurna), prototipe jadi (prototipe yang telah jadi tapi mungkin masih perlu disesuaikan dengan kebutuhan pengguna. (5) Tahap evaluasi prototipe Pada tahap ini dapat dilakukan evaluasi terhadap prototipe yang dihasilkan sehingga produk akhir semakin bagus dan kemungkinan kesalahan produk semakin kecil. (6) Tahap perbaikan prototipe Berdasarkan evaluasi oleh pengguna jika telah sesuai dengan yang diharapkan maka tahapan dilanjutkan ke rekayasa produk. Jika ada kesalahan maka akan diperbaiki, sesuai tanda panah dalam diagram, langkah pengerjaan kembali lagi pada langkah desain cepat dan seterusnya hingga prototipe tersebut sesuai dengan yang diharapkan. (7) Tahap rekayasa produk Pada tahap inilah produk benar-benar telah diimplementasikan hingga diperoleh hasil akhir yang siap digunakan.

Urutan tahapan pengembangan pada penelitian dengan paradigma prototyping diilustrasikan dalam gambar di bawah ini.

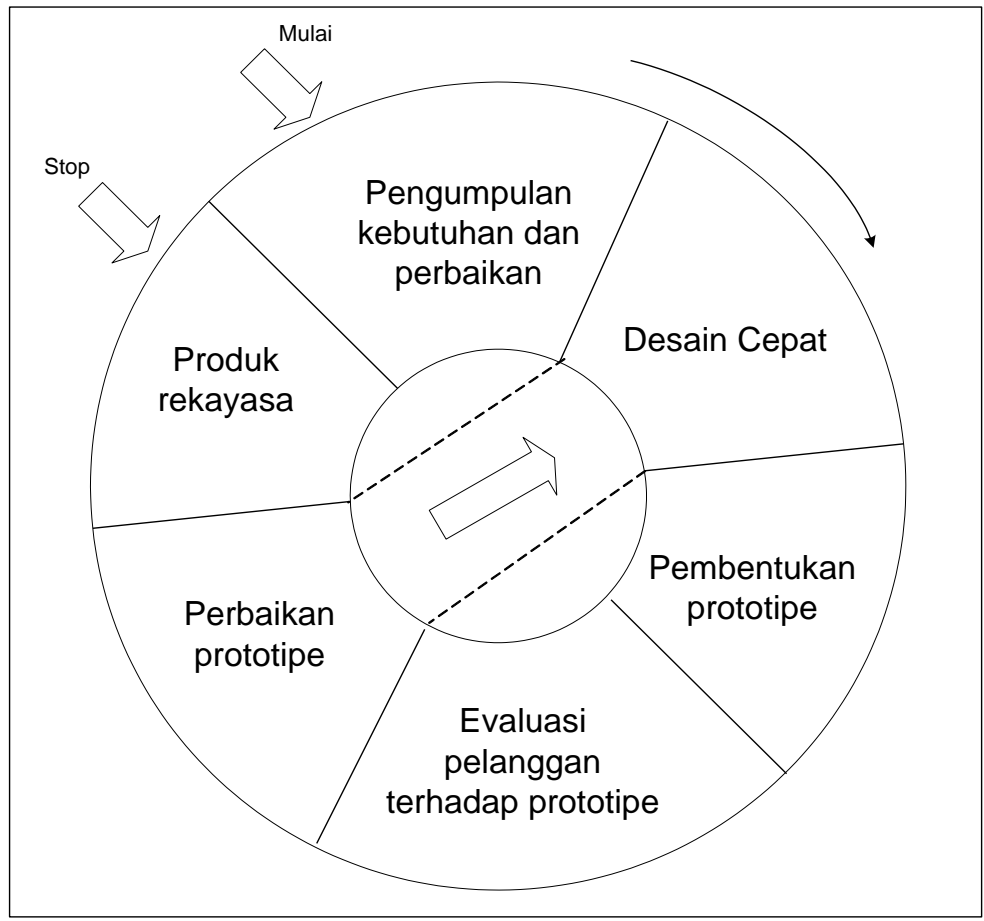

Gambar 1. Tahapan dalam metode prototyping 
Penelitian ini dilaksanakan di Perpustakaan Pusat Undiksha yang terletak di Jalan Udayana Singaraja. Subjek penelitian yang digunakan untuk melakukan evaluasi terhadap perangkat lunak sistem otomasi layanan sirkulasi dengan menggunakan RFID yang dihasilkan menggunakan buku-buku yang ada di Perpustakaan Pusat Undiksha yang dipilih menggunakan teknik random sampling atau dipilih secara acak. Objek penelitian dalam penelitian ini adalah perangkat lunak Sistem Otomasi Layanan Sirkulasi Perpustakaan dengan menggunakan RFID (Radio Frequency Identification). Metode pengumpulan data dilakukan dengan dokumentasi rancangan sistem dan coding (implementasi ke dalam bahasa pemrograman Borlan Delphi).

Pada penelitian ini, software diuji dengan menggunakan black box testing atau pengujian black box. Pengujian black box merupakan pendekatan komplementer dari teknik white box, karena pengujian black box diharapkan mampu mengungkap kelas kesalahan yang lebih luas dibandingka teknik white box. Pengujian black box berfokus pada pengujian persyaratan fungsional perangkat lunak, untuk mendapatkan serangkaian kondisi input yang sesuai dengan persyaratan fungsional suatu program.

Pengujian black box adalah pengujian aspek fundamental sistem tanpa memperhatikan struktur logika internal perangkat lunak. Metode ini digunakan untuk mengetahui apakah perangkat lunak berfungsi dengan benar. Pengujian black box merupakan metode perancangan data uji yang didasarkan pada spesifikasi perangkat lunak. Data uji dibangkitkan, dieksekusi pada perangkat lunak dan kemudian keluaran dari perangkat lunak dicek apakah telah sesuai dengan yang diharapkan. Pengujian black box berusaha menemukan kesalahan dalam kategori : (1) Fungsi - fungsi yang tidak benar atau hilang; (2) Kesalahan interface; (3) Kesalahan dalam struktur data atau akses database eksternal (4) Kesalahan kinerja; (5) Inisialisasi dan kesalahan terminasi

\section{HASIL DAN PEMBAHASAN}

Penelitian ini merupakan penelitian pengembangan perangkat lunak dimana langkah-langkah pengembangan aplikasi sistem otomasi layanan sirkulasi dengan menggunakan RFID di Perpustakaan Universitas Pendidikan Ganesha mengikuti paradigm pengembangan perangkat lunak.

\section{Analisis Kebutuhan Software}

Pada tahap ini peneliti melakukan analisis kebutuhan software yang digunakan dalam pengembangan aplikasi sistem otomasi layanan sirkulasi dengan menggunakan RFID, adapun software yang digunakan dalam pengembangan ini adalah:

1. Software Borlan Delphi yang digunakan untuk membangun aplikasi sistem otomasi layanan sirkulasi dengan menggunakan RFID.

2. Software MySQL yang digunakan untuk membuat database aplikasi 
sistem otomasi layanan sirkulasi dengan menggunakan RFID.

\section{Analisis Kebutuhan Hardware}

Pada tahap ini peneliti melakukan analisis batasan hardware yang dapat digunakan dalam implementasi aplikasi sistem otomasi layanan sirkulasi dengan menggunakan RFID. Hardware yang digunakan dalam pengembangan aplikasi ini adalah RFID reader dan RFID tag. RFID reader merupakan perangkat yang berfungsi untuk mengidentifikasi RFID tag dan mendapatkan nomor ID dengan menggunakan frekwensi radio, sedangkan Tag atau sering juga disebut dengan transponder berupa benda kecil yang biasanya diletakkan pada barang atau suatu produk. Untuk uji coba perangkat lunak sistem otomasi layanan sirkulasi dengan menggunakan RFID digunakan RFID reader dengan tipe ID 12 frekuensi 125 $\mathrm{KHz}$ dan RFID tag yang berfungsi sebagai transponder yang berisikan data dengan frekuensi $125 \mathrm{KHz}$.

\section{Analisis Perangkat Lunak}

Pada tahap ini peneliti melakukan analisis perangkat lunak aplikasi sistem otomasi layanan sirkulasi dengan menggunakan RFID yang akan dibangun meliputi analisis kebutuhan perangkat lunak, analisis tujuan perangkat lunak, model fungsional perangkat lunak dan perancangan perangkat lunak.

\section{Kebutuhan Perangkat Lunak}

Dari hasil analisis data-data diperoleh dilapangan mengenai bagaimana proses layanan peminjaman buku, layanan pengembalian buku dan layanan perpanjangan buku di Perpustakaan Universitas Ganesha, maka diperlukan sebuah perangkat lunak yang dapat mempermudah dan mengurangi kesalahan petugas dalam memberikan layanan sirkulasi (peminjaman, pengembalian dan perpanjangan buku) di perpustakaan.

\section{Tujuan Perangkat Lunak}

Berdasarkan tujuan yang ingin dicapai oleh penelitian ini, perangkat lunak sistem otomasi layanan sirkulasi dengan menggunakan RFID diharapkan dapat menjadi sebuah perangkat lunak yang dapat membatu mengefisiensikan dan mempermudah serta mengurangi tingkat kesalahan petugas dalam melakukan pekerjaan layanan sirkulasi (peminjaman, pengembalian dan perpanjangan buku) di perpustakaan Universitas Pendidikan Ganesha.

\section{Model Fungsional perangkat Lunak}

Model fungsional perangkat lunak memberikan gambaran umum serta aliran data yang terjadi antar prosesproses dalam perangkat lunak. Aliran data tersebut akan mendefinisikan masukan dan keluaran yang terdapat pada masing-masing proses yang terjadi, sehingga hubungan antar proses dapat terlihat dengan jelas. Model fungsional yang akan digunakan untuk mendeskripsikan perangkat lunak adalah Data Flow Diagram (DFD).

Diagram Konteks merupakan diagram level paling atas dalam DFD. Diagram ini menggambarkan bagian 
paling umum dari keseluruhan kebutuhan fungsional perangkat lunak. Pada diagram ini terdapat dua buah entitas yaitu anggota dan perpustakaan. Pada proses sirkulasi terdapat beberapa proses. Proses detail dari proses sirkulasi buku pada diagram konteks, ada 4 proses yaitu proses pengecekan identitas anggota, proses pengecekan data buku yang dipinjam/ dikembalikan, proses pengecekan status buku yang dipinjam/dikembalikan dan proses pengecekan status dipinjam/ dikembalikan.

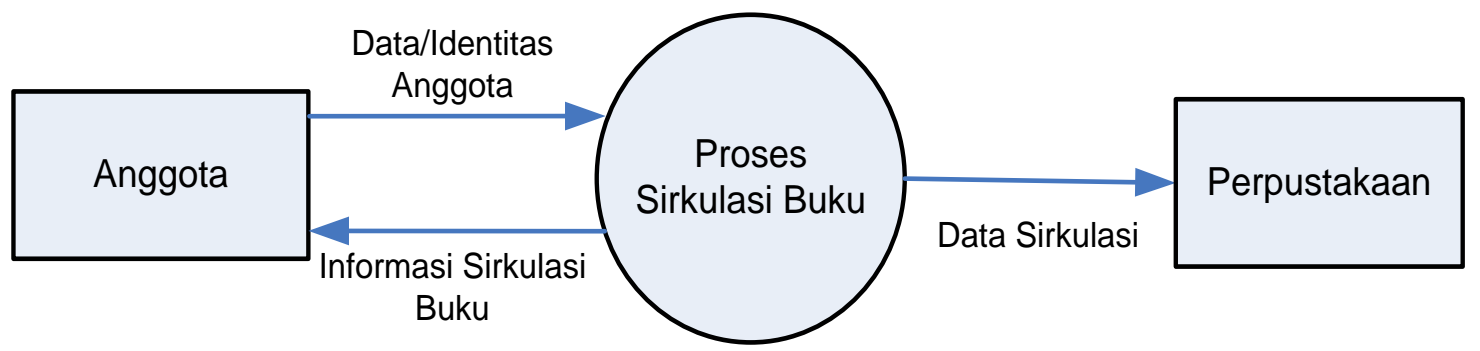

Gambar 2. Diagram Konteks (DFD level 0)

\section{Rancangan Perangkat Lunak}

Perancangan perangkat lunak merupakan proses merancang perangkat lunak sebelum diimplementasikan ke dalam bahasa pemrograman. Perancangan perangkat lunak sistem otomasi layanan sirkulasi dengan menggunakan RFID terdiri dari perancangan menu dan perancangan GUI (Graphical User interface).

a. Perancangan Menu memberikan gambaran menu yang disediakan pada perangkat lunak. Perancangan perangkat lunak ini terdiri dari menu utama dan 3 buah pilihan menu dari menu utama yaitu menu file, menu sirkulasi, dan menu about (user manual penggunaan program).

b. Perancangan GUI (Graphical User interface) memberikan gambaran antar muka yang akan diimplementasikan berdasarkan struktur menu dari perangkat lunak. Berikut ini merupakan bagan dari perancangan menu perangkat lunak. 


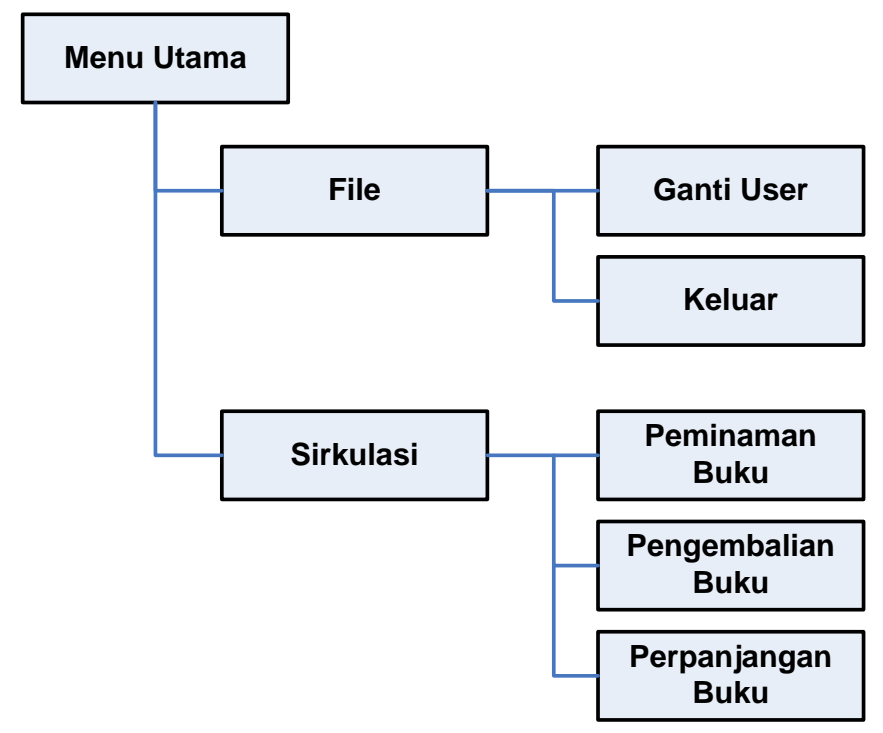

Gambar 3 Perancangan menu sistem otomasi layanan sirkulasi perpustakaan dengan RFID

\section{Rancangan Tabel}

Untuk pengembangan perangkat lunak sistem otomasi layanan sirkulasi dengan menggunakan RFID ini, dibutuhkan beberapa informasi yang berhubungan dengan data anggota, data buku, data sirkulasi, dan data denda. Data tersebut kemudian dikelompokkan menjadi beberapa tabel anggota, tabel buku, tabel inventaris buku, tabel sirkulasi dan tabel denda. Gambar berikut ini menggambarkan relasi antar tabel dalam sistem ini. 


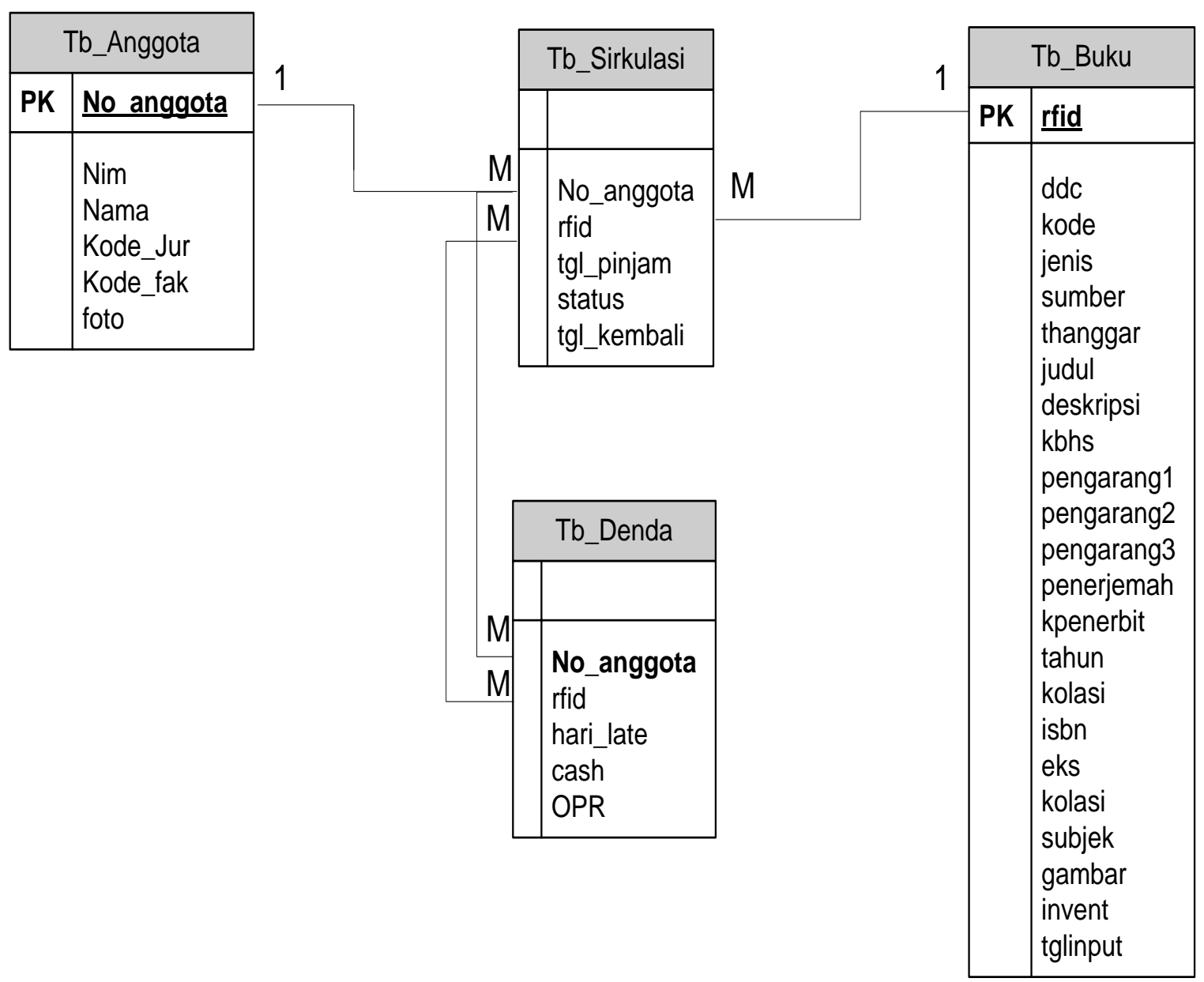

Gambar 3. Relasi Tabel

\section{Implementasi Perangkat Lunak}

Berdasarkan rancangan yang telah dibuat, maka langkah selanjutnya adalah implementasi perangkat lunak sesuai dengan rancangan yang telah dibuat. Berikut adalah antar muka sistem dari beberapa proses yang ada dalam sistem otomasi layanan sirkulasi perpustakaan dengan menggunakan RFID.
1. Antarmuka login pengguna digunakan oleh pengguna untuk masuk ke sistem. Pengguna diminta untuk memasukkan username dan password untuk dapat mengakses menu yang ada pada sistem. Gambar 3 berikut ini adalah antarmuka atau tampilan login pengguna. 


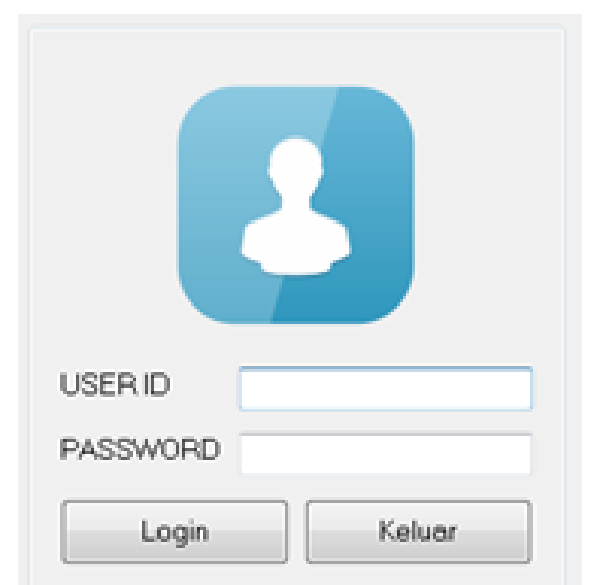

Gambar 4. Tampilan login pengguna

2. Antarmuka untuk peminjaman buku digunakan oleh pengguna untuk melakukan layanan peminjaman buku. Proses peminjaman buku diawali dengan pengguna memasukkan nomor di kartu anggota ke sistem, kemudian sistem membaca atau menscanning buku (yang disisipkan tag RFID), setelah terdata dan pengguna menyimpan data peminjaman tersebut. Peminjam akan menerima kartu anggota dan buku yang dipinjamnya. Gambar 5 berikut ini adalah antarmuka untuk peminjaman buku.

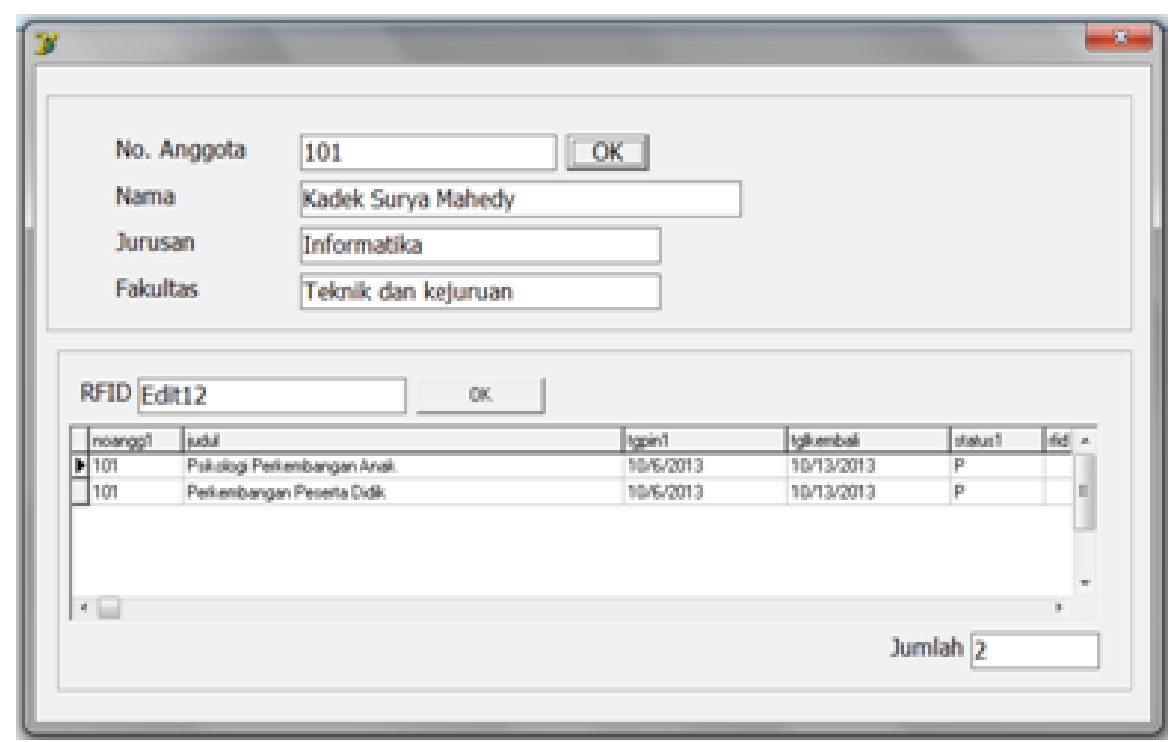

Gambar 5. Antarmuka peminjaman buku. 
3. Antarmuka untuk pengembalian buku digunakan oleh pengguna untuk melakukan layanan pengembalian buku. Proses pengembalian buku diawali dengan pengguna memasukkan nomor di kartu anggota ke sistem, kemudian sistem membaca atau menscanning buku (yang disisipkan tag RFID) yang dipinjam, setelah sistem memproses pengembalian buku tersebut. Apabila pengembalian buku mengalami keterlambatan maka sistem akan mengenakan denda maka anggota diharuskan membayar denda sesuai dengan yang tercatat di sistem. Gambar 5 berikut ini adalah antarmuka untuk pengembalian buku.

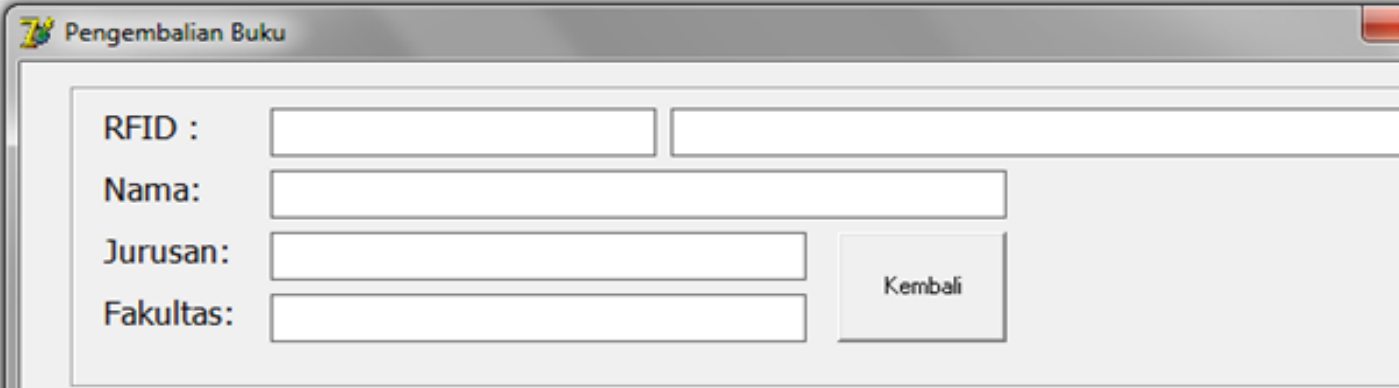

Gambar 6. Antarmuka untuk pengembalian buku

4. Antarmuka untuk perpanjangan buku digunakan oleh pengguna untuk melakukan layanan perpanjangan buku. Proses pengembalian buku diawali dengan pengguna memasukkan nomor di kartu anggota ke sistem, kemudian sistem memproses perpanjangan buku, setelah itu pengguna menyimpan data perpanjangan masa peminjaman tersebut. Gambar 6 berikut ini adalah antarmuka untuk perpanjangan buku.

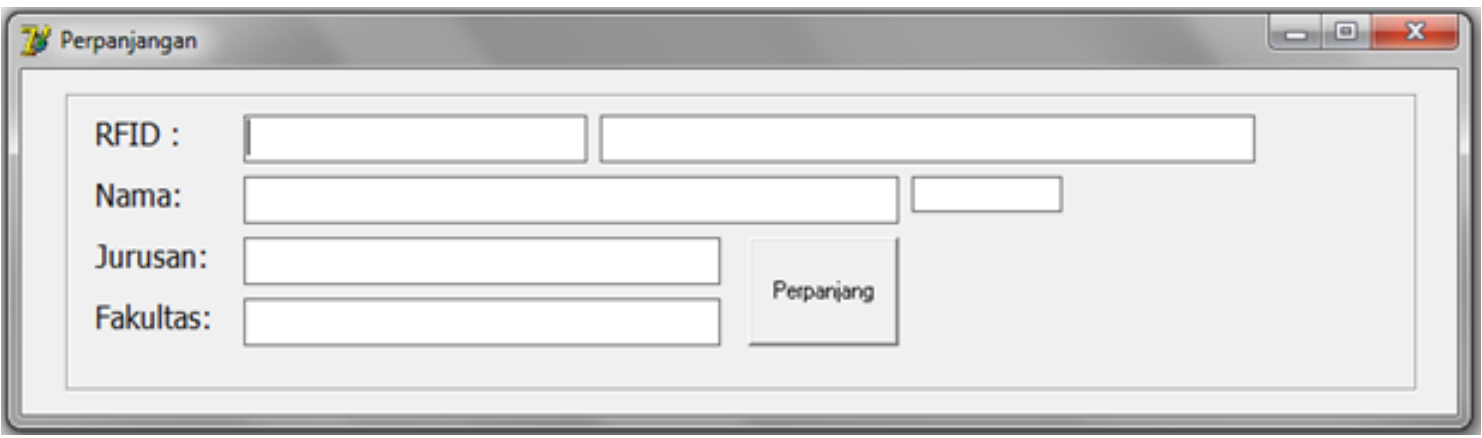

Gambar 7. Antarmuka untuk perpanjangan buku 


\section{Pengujian Perangkat Lunak}

Pengujian secara

teknik (technical test) perangkat lunak sistem otomasi layanan sirkulasi perpustakaan dengan menggunakan RFID ini dilakukan setelah proses implementasi selesai dilakukan. Teknik pengujian perangkat lunak yang digunakan adalah Pengujian blackbox (blackbox testing). Pengujian blackbox (blackbox testing) adalah salah satu metode pengujian perangkat lunak yang berfokus pada sisi fungsionalitas, khususnya pada input dan output aplikasi (apakah sudah sesuai dengan apa yang diharapkan atau belum). Tahap pengujian atau testing merupakan salah satu tahap yang harus ada dalam sebuah siklus pengembangan perangkat lunak (selain tahap perancangan atau desain).

Pengujian secara teknik dilakukan oleh peneliti untuk menguji alur proses dari perangkat lunak berdasarkan standar paradigma prototyping. Pengujian dilakukan pada proses dalam sistem otomasi layanan sirkulasi dengan menggunakan RFID meliputi :

1. Proses login pengguna,

2. Proses peminjaman buku,

3. Proses pengembalian buku dan

4. Proses perpanjangan buku.

\section{SIMPULAN DAN SARAN}

Setelah melakukan analisis, perancangan dan implementasi perangkat lunak Sistem Otomasi Layanan Sirkulasi Perpustakaan dengan Menggunakan RFID pada Perpustakaan Universitas Pendidikan
Ganesha, maka dapat disimpulkan sebagai berikut :

1. Teknologi RFID (Radio Frequensi Identification) merupakan sebuah teknologi compact wireless yang unggul yang dapat digunakan sebagai pengganti atau pelengkap sistem penomoran identifikasi buku di perpustakaan sehingga memudahkan dalam identifikasi bahan pustaka.

2. Sistem Otomasi Layanan Sirkulasi Perpustakaan dengan Menggunakan RFID dikembangkan sebagai alternatif pemberian layanan kepada pemustaka. Pemanfaatan RFID dalam sistem otomasi layanan sirkulasi perpustakaan membantu proses otomatisasi identifikasi buku dalam proses layanan sirkulasi (peminjaman buku, pengembalian buku dan perpanjangan masa peminjaman buku) serta pengelolaan koleksi buku, sehingga diharapkan mampu memberi kemudahan serta efisiensi waktu pemberian layanan petugas perpustakaan kepada pemustaka.

Untuk pengembangan Penelitian ini, penulis menyarankan hal-hal sebagai berikut:

1. sistem ini hanya menangani masalah layanan sirkulasi di perpustakaan yang meliputi proses peminjaman buku, pengembalian buku, dan perpanjangan masa peminjaman buku, untuk selanjutnya dapat kembangkan sampai pada proses pelaporan dan pembuatan statistik. 
2. Dalam proses evaluasi perangkat lunak sistem otomasi layanan sirkulasi dengan menggunakan RFID, digunakan RFID dengan ID 12.

\section{UCAPAN TERIMA KASIH}

Penghargaan dan terima kasih diberikan kepada Direktur Pembinaan Penelitian dan Pengabdian kepada Masyarakat (Ditbinlitabmas) Direktorat Jenderal Pendidikan Tinggi Depdiknas, yang telah memberikan bantuan dana sehingga penelitian ini dapat berjalan sesuai rencana dan keinginan peneliti. Penelitian ini dibiayai dari dana DIPA Universitas Pendidikan Ganesha dengan SPK No: 102/UN48.14/ PL/2013, Tanggal 1 April 2013.

\section{DAFTAR PUSTAKA}

Bafadal Ibrahim. (2005). Pengelolaan Perpustakaan Sekolah. Bumi Aksara. Jakarta.

Hidayat,R. (2010). Teknologi Wireless RFID Untuk Perpustakaan Polnes : Suatu Peluang. Jurnal Informatika Mulawarman Vol 5 No 1.

Pathak, R., \& Joshi, S. (2009). Recent trends in RFID and a java based software framework for its integration in mobile phones. $\mathrm{AH}$ $\mathrm{ICl}$. First Asian Himalayas International Conference on.
Pressman, Roger S. (2002). Rekayasa Perangkat Lunak : Pendekatan Praktisi (Buku Satu). ANDI Yogyakarta. Yogyakarta.

Samekta Hadi, R. A. (2008). Implementasi Radio Frequency Identification (RFID) Pada Supply Chain. Konferensi dan Temu Nasional Teknologi Informasi dan Komunikasi untuk Indonesia. Jakarta.

Sanandra, R. (2009). Perancangan Stand Alone RFID Reader untuk Aplikasi Sistem Keamanan Pintu. Retrieved Maret 2012, from Digital library - Perpustakaan Pusat Unikom: http://222.124.203.59/gdl.php?mo $\mathrm{d}=$ browse\&op=read\&id= jbptunikompp-gdl-rahmansana19676\&q=Equipment

SD., D., C, D., \& HK, A. (2010). Sistem Otomasi Perpustakaan Dengan Menggunakan Radio Frequency Identification (RFID). Jurnal Informatika Mulawarman Vol 5 No, 1-7.

Sugiyono. (2009). Penelitian Kuantitatif Kualitatif dan $R \& D$. Alfabeta. Jakarta.

Want, R. (2006). An Introduction to RFID Technology. the IEEE CS and IEEE ComSoc. 